\title{
Comparison of rapid methods PBP2' detection, ORSAB and mecA for detection of methicillin- resistant Staphylococcus aureus (MRSA) in a tertiary care centre, Chennai, India
}

\author{
Latha Jayaraman ${ }^{1 *}$, Umamaheswari Subburaya $^{2}$ \\ From 2nd International Science Symposium on HIV and Infectious Diseases (HIV SCIENCE 2014) \\ Chennai, India. 30 January - 1 February 2014
}

\section{Background}

Early detection of MRSA in clinical specimens is imperative to prevent cross transmission, morbidity, mortality and overall cost of treatment. Additionally, rapid detection of MRSA helps in preventing superficial skin infection to become deep seated.

\section{Method}

Fifty isolates of MRSA from different specimens like blood, urine, exudates and respiratory were collected from 2010 to 2011. MRSA screen slide latex agglutination test kit (Denka Seikan, Japan) was used for PBP2' detection and Oxacillin Resistant Screen Agar Base (ORSAB) with supplement (Oxoid Ltd., UK) was used for detection of MRSA from the isolates with ATCC controls. The detection of mecA gene in the MRSA isolates was considered as the reference method for determining the sensitivity of each phenotype rapid method studied.

\section{Results}

All the 50 isolates of MRSA were positive for mecA by PCR. MRSA screen for PBP2' detection and ORSAB had a sensitivity of $93.75 \%$ and $95.8 \%$, respectively. Chi square statistical analysis was carried out for the comparison of the rapid methods. Chi square value was found to be $3.0928(p$ value $=0.07864)$ and $2.0408(p$ value $=0.153127)$ at $5 \%$ level of significance. OR (Odds ratio) $=7.4421(95 \%$ $\mathrm{CI}=0.3744-147.9331)$ and $\mathrm{OR}=5.2062(95 \% \mathrm{CI}=0.2436-$ 111.2444), respectively.

\footnotetext{
* Correspondence: lathaj_73@yahoo.co.in

${ }^{1}$ Department of Microbiology, Sri Ramachandra University, Chennai, India
} Full list of author information is available at the end of the article

\section{Conclusion}

In the present study, we found that the difference in sensitivity between PCR for mecA and the phenotype rapid methods is statistically not significant. Therefore, we conclude that phenotype rapid methods can be used for the detection of MRSA from clinical isolates in low resource health care settings.

\section{Authors' details}

'Department of Microbiology, Sri Ramachandra University, Chennai, India. ${ }^{2}$ Department of Pharmacology, Sri Ramachandra University, Chennai, India.

Published: 27 May 2014

doi:10.1186/1471-2334-14-S3-P31

Cite this article as: Jayaraman and Subburaya: Comparison of rapid methods PBP2' detection, ORSAB and mecA for detection of methicillinresistant Staphylococcus aureus (MRSA) in a tertiary care centre, Chennai, India. BMC Infectious Diseases 2014 14(Suppl 3):P31.

Submit your next manuscript to BioMed Central and take full advantage of:

- Convenient online submission

- Thorough peer review

- No space constraints or color figure charges

- Immediate publication on acceptance

- Inclusion in PubMed, CAS, Scopus and Google Scholar

- Research which is freely available for redistribution

Submit your manuscript at www.biomedcentral.com/submit
() Biomed Central 